\title{
MIR148B wt Allele
}

National Cancer Institute

\section{Source}

National Cancer Institute. MIR148B wt Allele. NCI Thesaurus. Code C82103.

Human MIR148B wild-type allele is located in the vicinity of 12 q13.13 and is 98 bases in length. This allele, which encodes MIR148B pre-miRNA, plays a role in the regulation of gene expression. Alteration in the expression of this gene is associated with the development of asthma. 